\title{
Predatory impact of killer whales on pinniped and penguin populations at the Subantarctic Prince Edward Islands: fact and fiction
}

R.R. Reisinger*, P.J.N. de Bruyn and M.N. Bester

Mammal Research Institute, Department of Zoology and Entomology, University of Pretoria, Private Bag X20, Hatfield, 0028, South Africa

*corresponding author: rrreisinger@zoology.up.ac.za

\section{ABSTRACT}

Killer whales are the oceans' apex predators and their potential effects on ecosystems have been demonstrated. In the Southern Ocean the role of killer whale predation in population declines of southern elephant seals remains largely speculative. We aimed to assess whether top-down control of pinniped and penguin populations at the Subantarctic Prince Edward Islands is generally plausible using a simple process of elimination. Based on published data we predicted the energetic ingestion requirements of adult male and

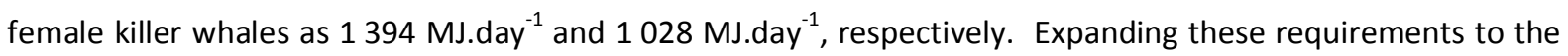
37 killer whales photographically identified at the Prince Edward Islands, the population requires $40600 \mathrm{MJ} \cdot$ day $^{-1}$. Based on available energy density and mass data, we predicted the energy content of available pinniped and penguin prey and calculated the rates at which killer whales would consume these prey in various scenarios. Penguins and Subantarctic fur seals are relatively insensitive to killer whale predation owing to their large population sizes (10 000s $-100000 s)$. Conversely, the smaller populations (100s $-1000 s)$ of Antarctic fur seals and southern elephant seals are sensitive to predation, particularly the latter as they have a high energy content (ca. $2000-9000 \mathrm{MJ}$ ). Populations of these seals are currently increasing or stable and we conclude that presently killer whale predation is not driving population declines, although they clearly have the potential for regulation of these smaller populations. Thus, if population sizes were reduced by bottom-up processes, if killer whale diet shifted, or if prey availability changed, top-down predation by killer whales could 
become significant. By eliminating the possibility of some predation scenarios, we are better able to concentrate future efforts on plausible predation effects.

\section{KEYWORDS}

Orcinus orca; top-down control; predator-prey interactions; elephant seal; fur seal; penguin; apex predator

RUNNING HEAD

Impact of killer whales on pinnipeds and penguins

\section{INTRODUCTION}

Due to their size, mobility and energy requirements, large predators can have marked effects on ecosystems despite their relative rarity (e.g., Terborgh, 1990). However, assessing the roles of large carnivores in an ecosystem is difficult due to their rarity and mobility (Williams et al., 2004) and can be even more difficult for marine mammals which often hunt at depth (Davis et al., 1999). Investigations of the predatory role of killer whales (Orcinus orca) have thus utilized energetic analyses to determine the strength of their top-down effects (Barrett-Lennard et al., 1995; Estes et al., 1998; Williams et al., 2004, Branch \& Williams, 2006; Williams, 2006); incorporating information about their abundance, diet and per capita ingestion rate (which is determined by their metabolic rate and prey energetic content [Williams et al., 2004]).

Killer whale predation has been suggested as a major factor in the southern elephant seal (Mirounga leonina) declines at least at the Subantarctic Prince Edward Islands (PEIs) and Îles Crozet (Condy, van Aarde \& Bester, 1978; Guinet, Jouventin \& Weimerskirch, 1992) and several authors have alluded to the top-down influences of killer whales on pinniped populations at the PEls (Keith et al., 2001; Pistorius et al., 2002; Tosh, de Bruyn \& Bester, 2008; de Bruyn, 2009; de Bruyn et al., 2009a). However, only a single study has followed a quantitative approach to this question, albeit at a regional scale. Branch and Williams (2006) found it plausible that 
declines in elephant seals and southern sea lions (Otaria flavescens) in the Southern Ocean were due to increased predation by killer whales following the depletion of their preferred great whale prey.

The Southern Ocean ecosystem has undergone large-scale changes brought about by top predator removals (Laws, 1977), commercial fishing (Ainley \& Blight, 2009) and climate change (Weimerskirch et al., 2003). To suggest that the PEls marine ecosystem is pristine would be symptomatic of "shifting baseline syndrome" (Pauly, 1995). Nevertheless, to critically assess the role of killer whales in the PEls marine ecosystem, a "model system" with broad relevance for the Subantarctic (Chown \& Froneman, 2008), we quantified the potential predatory impact of killer whales on pinniped and penguin populations based on the theoretical energy requirements of killer whales. Our intention is not to test any specific hypothesis of predation pressure explicitly, given the relative paucity of data on killer whales at this locality. Instead, we aim to assess whether top-down control of pinniped and penguin populations at the PEls is broadly plausible currently, following an eliminatory approach. We suggest that this approach of eliminating scenarios on a scale of "presumably unrealistic to probable," can be broadly applicable for predator-prey studies to better isolate key aspects for future research focus.

\section{METHODS}

\section{The Prince Edward Islands}

The Subantarctic PEls comprise Marion Island $\left(296 \mathrm{~km}^{2} ; 46^{\circ} 54^{\prime} \mathrm{S}, 37^{\circ} 45^{\prime} \mathrm{E}\right)$ and, approximately $19 \mathrm{~km}$ to the north east, the smaller Prince Edward Island $\left(45 \mathrm{~km}^{2} ; 46^{\circ} 38^{\prime} \mathrm{S}, 37^{\circ} 57^{\prime} \mathrm{E}\right)$. The PEIs are situated in the southern Indian Ocean with the nearest landmass being the Îles Crozet (950 km to the east) at similar latitude. The interplay between the Antarctic Circumpolar Current and the prominent bottom topography of the South West Indian Ridge results in productive turbulent water masses around the PEIs (Ansorge \& Lutjeharms, 2005), sustaining the food web that supports the numerous mammal and bird species that breed there (Table 1). While penguins and seals forage tens to thousands of kilometres from the PEls, we assumed throughout this study that the only predators they had were killer whales inshore at the PEIs. 


\section{Killer whale population size, structure and seasonal occurrence}

From 2006 to 2009, 37 individuals were identified (19 adult females, 3 lactating adult females with calves, 7 adult males and 5 individuals of unknown age-sex class; Reisinger, de Bruyn \& Bester, in review). Killer whales occurrence inshore at the PEls peaks in April-May and September-December (Reisinger et al. in press). Killer whales were sighted on 80 days.year ${ }^{-1}$ in 2006-2009 (MRI unpublished data).

\section{Killer whale energy requirements}

To predict the energetic requirements of adult, free-ranging killer whales at the PEls we used Williams et al.'s (2004) allometric field metabolic rate regression determined from the measured field metabolic rate of smaller marine mammals.

$F M R=19.65 M_{b}^{0.756}$ Equation 1

Where $F M R$ is field metabolic rate in Watts and $M_{b}$ is body mass in kilograms.

We calculated likely masses for male and female killer whales at the PEls using Best's (2007) length-mass regression for killer whales from the southern African subregion.

$M_{b}=8.6791 L^{3.2769}$

Equation 2

Where $L$ is length in meters.

We used average lengths of $7.26 \mathrm{~m}$ (males) and $6.42 \mathrm{~m}$ (females), obtained from killer whales taken during Southern Hemisphere whaling operations (excluding "dwarf" individuals; Mikhalev et al., 1981). The resulting energy requirements were adjusted upwards for an assumed assimilation efficiency (metabolisable energy) of 84.7\% (Williams et al., 2004), giving the energy killer whales would need to ingest to meet basic energetic demands. These energetic requirements are for adult killer whales and assumed no growth or reproductive costs. However, we incorporated the additional energy requirements of lactating females (following Baird, 1994) not by adjusting their energy requirements, but by assuming that calves were of equivalent mass to their 
mothers (and thus had equivalent energetic requirements). This is because unweaned calves gain all their energy by suckling and accounts for the up to $100 \%$ increase in energy required by lactating female killer whales (Kriete, 1995). Daily per-capita energy (ingestion) requirements were multiplied by the population size and composition to determine the daily population energy (ingestion) requirements.

\section{Prey energy content}

The energy density (energy content per mass) and average mass of prey consumed by killer whales at the PEIs was obtained from published and unpublished data - energy density was multiplied by the average mass of a prey type to give the prey type's average energy content (Table 3).

\section{$\underline{\text { Prey consumed }}$}

To calculate the number of seals and penguins consumed, we divided the killer whale population's total energetic requirement by the calculated average energy content of each prey type, assuming the entire prey item was consumed. ( $c f$. Baird \& Dill, 1996). Partial consumption of select portions of certain prey types (e.g., Pitman \& Durban, 2010) could presumably result in underestimation of the number of prey killed, and while this serves as a precaution when drawing conclusions, observational data to account for this do not exist. To predict the "worst case scenario" or maximum predatory impact for each prey type, we initially assumed that killer whales consumed each prey type exclusively (1). Based on these daily consumption rates we calculated the proportion of available prey (i.e., the percentage of the total prey population at the PEls) consumed over time. We then considered more realistic scenarios: (2) killer whale diet comprised equal proportions (energetically) of each prey type, (3) killer whale diet comprised proportions of available prey type relative to their proportional energetic biomass in the PEls system, (4) diet comprised prey proportions relative to their abundance, and (5) diet comprised prey proportions according to their energy content (i.e. preference for prey was based on its energy content relative to that of other prey).

We then assessed predatory impact at various prey population sizes of the three prey types identified (above) to be most sensitive to killer whale predation: Antarctic fur seal (Arctocephalus gazella) pups, Antarctic fur seals and elephant seal pups (see Results, Fig. 1). We assumed killer whales preyed exclusively on each prey type and predation mortality was $10 \%, 20 \%$ and $40 \%$ of the current prey population size. Keeping the absolute 
rate of predation constant (i.e., assuming that killer whales showed no total response to changing prey abundance; see Discussion), we varied prey population size to broadly predict at what population size predation mortality would become unsustainable, causing the prey population to decline markedly or be exterminated.

\section{RESULTS}

We calculated average masses of $5750 \mathrm{~kg}$ and $3843 \mathrm{~kg}$ for adult males and females, respectively (using Equation 2). Adult males and females were thus predicted (using Equation 1) to have field metabolic rates of $13667 \mathrm{~W}$ and $10078 \mathrm{~W}$, respectively, requiring the ingestion of $1394 \mathrm{MJ}_{\text {.day }}{ }^{-1}$ and $1028 \mathrm{MJ}$.day ${ }^{-1}$ (Table 2 ). Despite the large body mass estimated for PEls killer whales, per-animal and mass-specific energy (ingestion) requirements are comparable to estimates in previous studies (Table 2), particularly those for free-ranging killer whales. Expanding these requirements to the entire known population (37 individuals), killer whales at the PEls would need to ingest $40600 \mathrm{MJ}_{\text {day }}{ }^{-1}$. Energy densities for PEls prey were comparable to those estimated for similar prey in other studies (Table 3).

The large numbers of prey required to sustain the PEls killer whale population, assuming killer whales feed on each prey type exclusively, are shown in Table 4. When viewed as proportions of the available prey, Antarctic fur seal pups, Antarctic fur seal adults and elephant seal pups experience high relative predation pressure, as evidenced by the gradient of the respective lines in Fig. 1a. Other prey types experience relatively little predation pressure nearshore around the PEls. When each prey type is assumed to comprise an equal proportion of killer whale diet (11\% each; Fig. $1 b)$ predation pressure on each prey type obviously decreases substantially, although Antarctic fur seal pups still experience relatively high predation pressure and Antarctic fur seals and elephant seal pups experience moderate pressure. Other prey types experience very little predation pressure in this scenario. If prey are assumed to comprise proportions of killer whale diet relative to their proportional energetic biomass in the PEls system (Fig. 1C), each prey type experiences identical, low predation pressure. If diet is assumed to comprise prey proportions relative to their abundance (Fig. 1d), rockhopper (Eudyptes chrysocome) and macaroni penguins (E. chrysolophus) experience moderate predation pressure due to their large population sizes but relatively low energy content, while other prey types 
experience low predation pressure. Finally, if diet is assumed to comprise prey proportions relative to their energy content (Fig. 1e), elephant seal pups experience relatively high predation pressure due to their small population size and high energy content and elephant seal adults and Antarctic fur seal pups experience moderate predation pressure.

The results of varying prey population size on predation mortality (Fig. 2) indicate that, at relatively low predation rates ( $10 \%$ predation mortality at current population size) seal populations would have to dwindle dramatically before predation mortality becomes unsustainable. A simple common sense calculation shows that populations would have to be literally decimated before predation mortality becomes $100 \%$. For elephant seal pups, predation mortality becomes $80 \%$ below 100 pups (Fig. 2a), for Antarctic fur seal pups below 500 pups (Fig. 2b), and for Antarctic fur seals below 1000 individuals (Fig. 2c).

Due to their high energy content (Table 3) and small population size (Fig. 2a) elephant seal pups are likely most sensitive to killer whale predation. We therefore present the potential impact of killer whale predation on elephant seal pups on a small temporal scale (Fig. 3), given their short availability as prey. Assuming that killer whales meet their energy needs by preying exclusively on elephant seal pups, Fig. 3 shows that the currently observed first year mortality, $\sim 40 \%$ (de Bruyn, 2009), is reached two weeks after weaning, or about a month after birth. Assuming most pups disperse 1 - 2 months after weaning, the predation levels required to produce the observed $40 \%$ first year mortality would be $50 \%$ - $25 \%$ of the maximum rate (the rate where killer whales feed exclusively on elephant seal pups). These lower rates correspond, respectively, to the killer whale population predating approximately 9 and 13 fewer pups daily.

\section{DISCUSSION}

The predatory impact of killer whales at the PEls is determined by what proportion of their prey populations they consume over time. Fig. $1 a$ illustrates the potential magnitude of killer whales' impact on their prey populations, showing that they can consume a substantial number of prey items, although this arguably only represents a considerable proportion of elephant seal pups, Antarctic fur seal pups, and Antarctic fur seal populations. Assuming exclusive predation, elephant seal pups would be exterminated in approximately 38 
days, Antarctic fur seal pups in 6 days and Antarctic fur seals in 37 days. All other prey types could support killer whales for more than 100 days, assuming negligible non-predatory mortality levels of prey and unchanged predation pressure by other predators.

First year survival for elephant seals at Marion Island is $58 \%$ and $63 \%$ for males and females, respectively, and adult survival is around $70 \%$ and $80 \%$ for males and females, respectively (de Bruyn, 2009). Assuming this mortality is entirely due to predation, elephant seal pups would sustain killer whales for approximately 15 days, and adult elephant seals would sustain them for more than 100 days (Fig. 1a). Demographic data are unavailable for fur seals and penguins at Marion Island but for Antarctic fur seals at Bird Island, South Georgia, first year survival was estimated at $65 \%$ and adult female survival at $90 \%$ (Payne, 1977). Using these figures, Antarctic fur seal pups could support killer whales for little more than 1 day and adults for approximately 5 days. Subantarctic fur seals (A. tropicalis) at Île Amsterdam, Indian Ocean, have a pup survival rate of $48 \%$ (Beauplet et al., 2005) and adult female survival is around 90\% (Beauplet et al., 2006). Assuming these rates, Subantarctic fur seal pups could support killer whales for 54 days, and adults for more than 114 days. King penguins (Aptenodytes patagoniucs) at the Îles Crozet have survival rates of 90\% (Saraux et al. 2011), and could thus support killer whales for 53 days. Annual survival in macaroni penguins is approximately $77 \%$ (Williams, 1995) and 84\% in rockhopper penguins at île Amsterdam and île Saint Paul (Guinard et al., 1998), and these prey could thus support killer whales for 177 days and 20 days, respectively. Simply summing these figures (539 days) shows that there are sufficient prey resources to support killer whales at the PEls annually assuming exclusive, sequential predation on each species. When viewed as a simple "available prey" scenario without the occurrence, behaviour and growth rate (or its potential) of these prey taken into account, this indicates that prey mortality rates cannot escalate enough to cause population declines. However, various factors will affect diet composition. For comparison, in the Aleutian Islands the population of 170 killer whales, feeding exclusively on each prey species, would exterminate minke whales (Balaenoptera acutorostrata), harbour seals (Phoca vitulina), harbour porpoises (Phocoena phocoena) and Steller sea lions (Eumetopias jubatus) within 6 to 12 months. Sea otters would be eliminated in two days. Together these species would sustain killer whales for three years. Dall's porpoises (Phocoenoides dalli) would be eliminated in three years (Williams, 2006). 


\section{Diet composition and prey choice}

The predation rates presented in Fig. $1 a$ assume that killer whales prey exclusively on a certain prey type - an assumption we know to be incorrect from observations at the PEls and studies elsewhere (e.g, Condy et al., 1978; Guinet, 1992, Ford et al., 1998). The predatory impact of killer whales at the PEls will therefore be determined largely by what prey killer whales actually include in their diet, and in what proportions, more realistically reflected in one of the scenarios presented in Fig. $1(b-e)$. The dietary composition of killer whales at the PEls is unknown, but Reisinger et al. (in press) report killer whales preying on Subantarctic fur seals, elephant seals, king penguins and macaroni penguins.

\section{Predatory impact}

Despite the apparent magnitude of the predation rates (Fig. 1), at the PEls fur seal populations are increasing (Hofmeyr et al., 2006) after their near-extirpation by intensive commercial harvesting (King, 1983). The elephant seal population is at least stable, likely increasing (de Bruyn, 2009; McMahon et al., 2009), and the king penguin population appears stable (Crawford et al., 2009). Macaroni and rockhopper penguin populations are declining, but this is speculated to be due to mass disease outbreaks and altered food availability (Crawford et al., 2003; 2009).

Bottom-up and top-down forces certainly both structure and affect ecosystems; accent must be placed on their relative roles and interactions. Because of the current trajectories of top predator populations at the PEIs we logically assume that currently killer whale predation pressure is not sufficient to cause declines in prey populations, although Fig. 1 certainly demonstrates the potential to do so for some species, and continued long-term monitoring of predator and prey populations is required.

When considering the effects of prey population size changes on predation mortality (Fig. $2 a-c$ ), it is apparent that reductions in population size of a few hundred animals are required before killer whale predation becomes a significant threat to the existence of such prey populations. However, if population sizes were to reach such low numbers, killer whale predation could certainly precipitate severe population declines. The nature of such interactions would, however, depend on the total response (numerical and functional response [Solomon, 1949]) of killer whales to changes in prey density. We have assumed no total response in Fig. 2 but 
killer whales are unlikely to show strong numerical responses to changes in prey abundance although functional responses have been suggested (Barrett-Lennard et al., 1995). It is difficult to predict the effects of predation on different prey population sizes at the PEIs, but it is reasonable to expect that small prey population will experience at least some increase in predation pressure (as shown in ecosystem simulations for predation on Steller sea lions in the North Pacific Ocean [Guénette et al., 2006]).

Fig. 3 shows how small changes in the number of elephant seal pups taken can result in large differences in mortality expressed as a percentage of the population. If the killer whale population at the PEls were to take 4 additional elephant seal pups daily, first year mortality in elephant seals could realistically double (Fig. 3). Small dietary shifts or changes in the availability of prey can thus have large impacts in small populations (as illustrated by Williams et al., 2004; Branch \& Williams, 2006).

In summary, the killer whale population at the PEls can consume a substantial number of prey items, but this only represents a considerable proportion of elephant seal pups, Antarctic fur seal pups and Antarctic fur seal adults - and only if killer whales specialize on these prey. Populations of pinnipeds are increasing or stable at the PEls, implying that killer whale predation is currently not causing population declines, however, predation mortality certainly dampens population growth. If these populations became very small because of bottomup processes, or if prey availability or killer whale diet changed, killer whales could have much stronger adverse population effects (cf. Cooper \& Stewart, 1983).

To more accurately quantify the predation effects of killer whales at the PEls and to move towards a better understanding of the PEls marine ecosystem, further data are required: killer whale diets should be accurately described and the energy density of prey measured; their temporal abundance and movement patterns should be investigated; elephant seal and killer whale mark-recapture programmes must continue in order to describe any changes in abundance and vital rates (de Bruyn et al., 2008; Reisinger et al., in review), and; fur seal abundance must continue to be monitored and demographic studies should be initiated. Moreover, data describing any changes in seal and penguin diets, as well as the risks these animals take to acquire food, are necessary. Given the paucity of data concerning killer whale diet and predation at the PEls, we have taken an 
extremely simple approach to assessing their predatory impact. Despite this, we have shown that simple calculations using available data can be used to assess which prey may be sensitive to predatory impacts, and under what conditions. Eliminating unlikely scenarios allows the fruitful direction of the proposed future research and this approach is broadly applicable in large predator studies.

\section{ACKNOWLEDGEMENTS}

We thank the South African Department of Environmental Affairs for providing logistical support within the South African National Antarctic Programme and the Department of Science and Technology (administered through the National Research Foundation) for funding the marine mammal monitoring programme at Marion Island. The Marion Island seal biologists of 2006, 2007 and 2008 are thanked for their killer whale observations. David Ainley and an anonymous reviewer provided valuable comments on this manuscript.

\section{REFERENCES}

Ainley, D.G. \& Blight, L.K. (2009). Ecological repercussions of historical fish extraction from the Southern Ocean. Fish Fish. 10, 13-38.

Ansorge, I.J. \& Lutjeharms, J.R.E. (2005). Direct observations of eddy turbulence at a ridge in the Southern Ocean. Geophys. Res. Lett. 32, L14601, doi: 10.1029/2005GL022588

Arnould, J.P.Y., Boyd, I.L. \& Speakman, J.R. (1996). Measuring the body composition of Antarctic fur seals (Arctocephalus gazella): validation of hydrogen isotope dilution. Physiol. Zool. 69, 93-116.

Baird, R.W. (1994). Foraging behaviour and ecology of transient killer whales (Orcinus orca). PhD thesis. Simon Fraser University, Vancouver.

Baird, R.W. \& Dill, L.M. (1996). Ecological and social determinants of group size in transient killer whales. Behav. Ecol. 7, 408-416.

Barrett-Lennard, L.G., Heise, K., Saulitis, E., Ellis, G. \& Matkin, C. (1995). The impact of killer whale predation on Steller sea lion populations in British Columbia and Alaska. Vancouver: North Pacific Universities Marine Mammal Research Consortium, University of British Columbia. 
Beauplet, G., Barbraud, C., Chambellant, M. \& Guinet, C. (2005). Interannual variation in the post-weaning and juvenile survival of subantarctic fur seals: influence of pup sex, growth rate and oceanographic conditions. J. Anim. Ecol. 74, 1160-1172.

Beauplet, G., Barbraud, C., Dabin, W., Küssener, C. \& Guinet, C. (2006). Age-specific survival and reproductive performances in fur seals: evidence of senescence and individual quality. Oikos 112, 430-441.

Best, P.B. (2007). Whales and dolphins of the southern African subregion. Cambridge: Cambridge University Press.

Bester, M.N. \& Hofmeyr, G.J.G. (2005). Numbers of elephant seals at Prince Edward Island, Southern Ocean. S. Afr. J. Wildl. Res. 35, 85-88.

Bester, M.N., Ryan, P.G. \& Visagie, J. (2009). Summer survey of fur seals at Prince Edward Island, southern Indian Ocean. Afr. J. Mar. Sci. 31, 451-455.

Branch, T.A. \& Williams, T.M. (2006). Legacy of industrial whaling. Could killer whales be responsible for declines of sea lions, elephant seals, and minke whales in the Southern Hemisphere? In Whales, Whaling, and Ocean Ecosystems: 262-278. Estes, J.A., DeMaster, D.P., Doak, D.F., Williams, T.M. \& Brownell, Jr. R.L. (Eds). Berkeley: University of California Press.

Cherel, Y., Charrassin, J.B. \& Handrich, Y. (1993). Comparison of body reserve buildup in prefasting chicks and adults of king penguins (Aptenodytes patagonicus). Physiol. Zool. 66, 750-770.

Chown, S.L. \& Froneman, P.W. (2008). The Prince Edward Islands in a global context. In The Prince Edward Islands. Land-sea interactions in a changing ecosystem: 1-16. Chown, S.L. \& Froneman, P.W. (Eds.). Stellenbosch: Sun Media.

Condy, P.R., van Aarde, R.J. \& Bester, M.N. (1978). The seasonal occurrence and behaviour of Killer whales Orcinus orca, at Marion Island. J. Zool. (Lond.) 184, 449-464.

Cooper, C.F. \& Stewart, B.S. (1983). Demography of northern elephant seals, 1911- 1982. Science 219, 969-971. Crawford, R.J.M., Cooper, J., Dyer, B.M., Greyling, M.D., Klages, N.T.W., Ryan, P.G., Petersen, S.L., Underhill, L.G., Upfold, L., Wilkinson, W., de Villiers, M.S., du Plessis, S., du Toit, M., Leshoro, T.M., Makhado, A.B., Mason, M.S., Merkle, D., Tshingana, D., Ward, V.L. \& Whittington, P.A. (2003). Populations of surfacenesting seabirds at Marion Island, 1994/95-2002/03. Afr. J. Mar. Sci. 25, 427-440. 
Crawford, R.J.M., Dyer, B.M., Cooper, J. \& Underhill, L.G. (2006). Breeding numbers and success of Eudyptes penguins at Marion Island, and the influence of mass and time of arrival of adults. CCAMLR Sci. 13, 175190.

Crawford, R.J.M., Whittington, P.A., Upfold, L., Ryan, P.G., Petersen, S.L., Dyer, B.M. \& Cooper, J. (2009) Recent trends in numbers of four species of penguins at the Prince Edward Islands. Afr. J. Mar. Sci. 31, 419-426.

Davis, R.W., Fuiman, L.A., Williams, T.M., Collier, S.O., Hagey, W.P., Kanatous, S.B., Kohin, S. \& Horning, M. (1999). Hunting behavior of a marine mammal beneath the Antarctic fast ice. Science 283, 993-996.

de Bruyn, P.J.N. (2009). Life history studies of the southern elephant seal population at Marion Island. PhD thesis. University of Pretoria, Pretoria.

de Bruyn, P.J.N., Bester, M.N., Carlini, A. \& Oosthuizen, W.C. (2009b). How to weigh an elephant seal with one finger: a simple three-dimensional photogrammetric application. Aquatic Biol. 5, 31-39.

de Bruyn, P.J.N., Tosh, C.A., Oosthuizen, W.C., Bester, M.N. \& Arnould, J.P.Y. (2009a). Bathymetry and frontal system interactions influence seasonal foraging movements of lactating subantarctic fur seals from Marion Island. Mar. Ecol. Prog. Ser. 394, 263-276.

de Bruyn, P.J.N., Tosh, C.A., Oosthuizen, W.C., Phalanndwa, M.V. \& Bester, M.N. (2008). Temporary marking of unweaned southern elephant seal (Mirounga leonina L.) pups. S. Afr. J. Wildl. Res. 38, 133-137.

Estes, J.A., Tinker, M.T., Williams, T.M. \& Doak, D.F. (1998). Killer whale predation on sea otters linking oceanic and nearshore ecosystems. Science $282,473-476$.

Forcada, J., Malone, D., Royle, J.A. \& Staniland, I.J. (2009). Modelling predation by transient leopard seals for an ecosystem-based management of Southern Ocean fisheries. Ecol. Model. 220, 1513-1521.

Ford, J.K.B., Ellis, G.M., Barrett-Lennard, L.G., Morton, A.B., Palm, R.S. \& Balcomb, III K.C. (1998). Dietary specialization in two sympatric populations of killer whales (Orcinus orca) in coastal British Columbia and adjacent waters. Can. J. Zool. 76, 1456-1471.

Guénette, S., Heymans, S.J.J., Christensen, V. \& Trites, A.W. (2006). Ecosystem models show combined effects of fishing, predation, competition, and ocean productivity on Steller sea lions (Eumetopias jubatus) in Alaska. Can. J. Fish. Aquat. Sci. 63, 2495-2517.

Guinard, E., Weimerskirch, H. \& Jouventin, P. (1998). Population changes and demography of the northern rockhopper penguin on Amsterdam and Saint Paul Islands. Colon. Waterbird. 21, 222-228. 
Guinet, C. (1991). Intentional stranding apprenticeship and social play in killer whales (Orcinus orca). Can. J. Zool. 69, 2712-2716.

Guinet, C. (1992). Comportement de chasse des orques (Orcinus orca) autour des iles Crozet. Can. J. Zool. 70, $1656-1667$

Guinet, C. \& Bouvier, J. (1995). Development of intentional stranding hunting techniques in killer whale (Orcinus orca) calves at Crozet Archipelago. Can. J. Zool. 73, 27-33.

Guinet, C., Jouventin, P. \& Weimerskirch, H. (1992). Population changes, movements of southern elephant seals on Crozet and Kerguelen Archipelagos in the last decades. Polar Biol. 12, 349-356.

Halsey, L.G., Butler, P.J., Fahlman, A., Bost, C.A., Woakes, A.J. \& Handrich, Y. (2008). Modelling the marine resources consumed in raising a king penguin chick: an energetics approach. Physiol. Biochem. Zool. 81, 856-867.

Hofmeyr, G.J.G., Bester, M.N., Makhado, A.B. \& Pistorius, P.A. (2006). Population changes in Subantarctic and Antarctic fur seals at Marion Island. S. Afr. J. Wildl. Res. 36, 55-68.

Keith, M., Bester, M.N., Bartlett, P.A. \& Baker, D. (2001). Killer whales (Orcinus orca) at Marion Island, Southern Ocean. Afr. Zool. 36, 163-175.

King, J.E. (1983) Seals of the World. Oxford: Oxford University Press.

Kriete, B. (1995). Bioenergetics in the killer whale, Orcinus orca. PhD thesis. University of British Columbia, Vancouver.

Laws, R.M. (1977). Seals and whales of the Southern Ocean. Philos. Trans. R. Soc. Lond. B Biol. Sci. 279, 81-96.

McMahon, C.R., Bester, M.N., Hindell, M.A., Brook, B.W. \& Bradshaw, C.J.A. (2009). Shifting trends: detecting environmentally mediated regulation in long-lived marine vertebrates using time-series data. Oecologia 159, 69-82.

Mikhalev, Y.A., Ivashin, M.V., Savusin, V.P. \& Zelenaya, F.E. (1981). The distribution and biology of killer whales in the southern hemisphere. Rep. Int. Whal. Comm. 31, 551-566.

Pauly, D. (1995). Anecdotes and the shifting baseline syndrome in fisheries. Trends Ecol. Evol. 10, 420.

Payne, M.R. (1977). Growth of a fur seal population. Philos. Trans. R. Soc. Lond. B Biol. Sci. 279, 67-79.

Pistorius, P.A., Taylor, F.E., Louw, C., Hanise, B., Bester, M.N., de Wet, C., du Plooy, A., Green, N., Klasen, S., Podile, S. \& Schoeman, J. (2002). Distribution, movement, and estimated population size of killer whales at Marion Island, December 2000. S. Afr. J. Wildl. Res. 32, 86-92. 
Pitman, R.L. \& Durban, J.W. (2010). Killer whale predation on penguins in Antarctica. Polar Biol. 33, 1589-1594.

Reisinger, R.R., de Bruyn, P.J.N. \& Bester, M.N. (in review). Mark-recapture abundance estimates of killer whales at Subantarctic Marion Island. Aquatic Biol.

Reisinger, R.R., de Bruyn, P.J.N., Tosh, C.A., Oosthuizen, W.C., Mufanadzo, N.T. \& Bester, M.N. (in press). Prey and seasonal abundance of killer whales at Subantarctic Marion Island. Afr. J. Mar. Sci.

Ryan, P.G. \& Bester, M.N. (2008). Pelagic predators. In The Prince Edward Islands: land-sea interactions in a changing ecosystem. Chown, S.L. \& Froneman, P.W. (Eds.). Stellenbosch: Sun Media.

Saraux, C., Le Bohec, C., Durant, J.M., Viblanc, V.A., Gauthier-Clerc, M., Beaune, D., Park, Y.-H., Yoccoz, N.G., Stenseth, N.C. \& Le Maho, Y. (2011). Reliability of flipper-banded penguins as indicators of climate change. Nature 469, 203-206.

Solomon, M.E. (1949). The natural control of animal populations. J. Anim. Ecol. 18, 1-35.

Stansby, M.E. (1976). Chemical characteristics of fish caught in the Northeast Pacific Ocean. Mar. Fish. Rev. 1198, 1-11.

Stirling, I. \& McEwan, E.H. (1975). The caloric value of whole ringed seals (Phoca hispida) in relation to polar bear (Ursus maritimus) ecology and hunting behavior. Can. J. Zool. 53, 1021-1027.

Terborgh, J. (1990). The role of felid predators in neotropical forests. Vida Silvestre Neotropical 2, 3-5.

Tosh, C.A., de Bruyn, P.J.N. \& Bester, M.N. (2008). Preliminary analysis of the social structure of killer whales, Orcinus orca, at subantarctic Marion Island. Mar. Mamm. Sci. 24, 929-940.

Weimerskirch, H., Inchausti, P., Guinet, C. \& Barbraud, C. (2003). Trends in bird and seal populations as indicators of a system shift in the Southern Ocean. Antarct. Sci. 15, 249-256.

Williams, T.D. (1995). The penguins Spheniscidae. Oxford: Oxford University Press.

Williams, T.M. (2006). Physiological and ecological consequences of extreme body size in whales: 191-201. In Whales, Whaling, and Ocean Ecosystems. Estes, J.A., DeMaster, D.P., Doak, D.F., Williams, T.M. \& Brownell, Jr. R.L. (Eds.). Berkeley: University of California Press.

Williams, T.M., Estes, J.A., Doak, D.F. \& Springer, A.M. (2004). Killer appetites: assessing the role of predators in ecological communities. Ecology 85, 3373-3384. 
TABLES

Table 1. Population sizes of seals and penguins at the Prince Edward Islands.

\begin{tabular}{|c|c|c|c|c|}
\hline Species & Pup production & Total population & Breeding pairs & Reference \\
\hline Subantarctic fur seal & $>30000$ & 150000 & - & $a, b$ \\
\hline Antarctic fur seal & $>1500$ & 5800 & - & $a, b$ \\
\hline Southern elephant seal & $>560$ & $>2100$ & - & $c, d$ \\
\hline King penguin & - & - & 67000 & e \\
\hline Gentoo penguin & - & - & $>1100$ & $\mathrm{e}$ \\
\hline Macaroni penguin & - & - & 302000 & e \\
\hline Rockhopper penguin & - & - & 80000 & e \\
\hline
\end{tabular}

${ }^{\mathrm{a}}$ Hofmeyr et al., 2006; ${ }^{\mathrm{b}}$ Bester, Ryan \& Visagie, 2009; ${ }^{\mathrm{C}}$ Bester \& Hofmeyr, 2005; ${ }^{\mathrm{d}}$ Ryan \& Bester, 2008; ${ }^{\mathrm{e}}$ Crawford et al., 2009. 
Table 2

Energy requirements of different age-sex classes of killer whales estimated by various studies (including this study).

\begin{tabular}{|c|c|c|c|c|c|c|c|c|}
\hline \multirow[b]{2}{*}{ Study } & \multirow{2}{*}{$\begin{array}{l}\text { Age-sex } \\
\text { class }^{a}\end{array}$} & \multirow{2}{*}{$\begin{array}{l}\text { Mass } \\
(\mathrm{kg})\end{array}$} & \multicolumn{2}{|c|}{ Energy requirement } & \multirow{2}{*}{$\begin{array}{l}A E^{b} \\
(\%)\end{array}$} & \multicolumn{2}{|c|}{ Ingestion requirement } & \multirow[b]{2}{*}{ Notes on method } \\
\hline & & & $\begin{array}{l}\text { Per animal } \\
\left(\text { MJ.day }^{-1}\right)\end{array}$ & 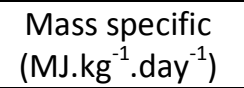 & & $\begin{array}{l}\text { Per animal } \\
\left(\text { MJ.day }^{-1}\right)\end{array}$ & 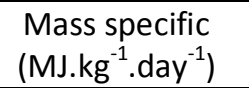 & \\
\hline \multirow[t]{4}{*}{ Baird, 1994} & AM & 5600 & - & - & - & 1453.66 & 0.26 & \multirow{4}{*}{$\begin{array}{l}\text { Field estimation of ingestion rates for mammal } \\
\text { eaters }\end{array}$} \\
\hline & $\mathrm{AF}$ & 4000 & - & - & - & 1038.33 & 0.26 & \\
\hline & SA & 2000 & - & - & - & 519.16 & 0.26 & \\
\hline & $\mathrm{C}$ & $4000^{c}$ & - & - & - & 1038.33 & 0.26 & \\
\hline \multirow[t]{2}{*}{ Kriete, 1995} & AM & 3750 & - & - & - & 753.62 & 0.20 & \multirow{2}{*}{ Ingestion rates of captive fish-eaters } \\
\hline & $\mathrm{AF}$ & 2692 & - & - & - & 607.09 & 0.23 & \\
\hline $\begin{array}{l}\text { Barrett-Lennard } \\
\text { et al., } 1995\end{array}$ & - & - & - & - & - & 921.10 & - & $\begin{array}{l}\text { 25\% upward adjustment of Kriete's (1995) } \\
\text { estimates applied to free-ranging mammal- } \\
\text { eaters }\end{array}$ \\
\hline \multirow{2}{*}{$\begin{array}{l}\text { Williams et al., } \\
2004\end{array}$} & AM & 4733 & 1019.49 & 0.25 & 84.70 & 1203.00 & 0.25 & \multirow{2}{*}{$\begin{array}{l}\text { Allometric regression of measured field } \\
\text { metabolic rates }\end{array}$} \\
\hline & $\mathrm{AF}$ & 2800 & 685.54 & 0.21 & 84.70 & 808.94 & 0.29 & \\
\hline \multirow[t]{2}{*}{ This study } & AM & 5750 & 1180.84 & 0.21 & 84.70 & 1394.15 & 0.24 & \multirow{2}{*}{$\begin{array}{l}\text { Using Williams et al.'s (2004) allometric } \\
\text { regression }\end{array}$} \\
\hline & $\mathrm{AF}$ & 3843 & 870.76 & 0.23 & 84.70 & 1028.05 & 0.27 & \\
\hline
\end{tabular}

${ }^{\mathrm{a}} \mathrm{AM}$ - adult male, AF - adult female, SA - subadult, C - calf; ${ }^{\mathrm{b}}$ Assimilation efficiency; ${ }^{\mathrm{c}}$ Mass accounts for the additional energetic requirements of the lactating mother. 
Table 3

Energy density, average mass and energy content of killer whales' pinniped and penguin prey occurring at the Prince Edward Islands, with other prey included for comparison.

\begin{tabular}{|c|c|c|c|c|}
\hline Prey type & 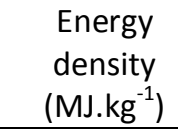 & $\begin{array}{l}\text { Average } \\
\text { mass } \\
(\mathrm{kg})\end{array}$ & $\begin{array}{c}\text { Energy } \\
\text { content (MJ) }\end{array}$ & Notes \\
\hline \multicolumn{5}{|l|}{ Seals } \\
\hline $\begin{array}{l}\text { Antarctic fur seal } \\
\text { pup }\end{array}$ & $8.24^{\mathrm{a}}$ & $11.24^{b}$ & 92.66 & \\
\hline $\begin{array}{l}\text { Antarctic fur seal } \\
\text { adult female }\end{array}$ & $10.59^{\mathrm{a}}$ & $30.6^{b}$ & 324.05 & \\
\hline $\begin{array}{l}\text { Subantarctic fur seal } \\
\text { pup }\end{array}$ & - & $12.70^{b}$ & 104.62 & $\begin{array}{l}\text { Assuming Antarctic fur seal pup energy } \\
\text { density }\end{array}$ \\
\hline $\begin{array}{l}\text { Subantarctic fur seal } \\
\text { adult female }\end{array}$ & - & $36.5^{\mathrm{b}}$ & 386.54 & $\begin{array}{l}\text { Assuming Antarctic fur seal adult female } \\
\text { energy density }\end{array}$ \\
\hline Elephant seal pup & $20.2^{c}$ & $116.46^{\mathrm{b}}$ & 2352.54 & \\
\hline Elephant seal & & $437^{d}$ & 8827.40 & $\begin{array}{l}\text { Assuming elephant seal pup energy } \\
\text { density. Average mass of adult females } \\
\text { and subadult males }\end{array}$ \\
\hline \multicolumn{5}{|l|}{ Penguins } \\
\hline King penguin adult & $11.16^{\mathrm{e}}$ & $14.3^{f}$ & 159.59 & $\begin{array}{l}\text { Average of pre-moult and pre-breeding } \\
\text { energy density; mass of incubating males } \\
\text { from Crozet }\end{array}$ \\
\hline $\begin{array}{l}\text { Macaroni penguin } \\
\text { adult }\end{array}$ & $9.6^{c}$ & $5.36^{\mathrm{g}}$ & 51.46 & \\
\hline $\begin{array}{l}\text { Rockhopper } \\
\text { penguin adult }\end{array}$ & - & $3.14^{\mathrm{g}}$ & 30.14 & $\begin{array}{l}\text { Assuming macaroni penguin energy } \\
\text { density }\end{array}$ \\
\hline \multicolumn{5}{|l|}{ For comparison } \\
\hline Sea otter adult & $7.58^{h}$ & - & - & \\
\hline $\begin{array}{l}\text { Steller's sea lion } \\
\text { pup }\end{array}$ & $10.97^{\mathrm{h}}$ & - & - & \\
\hline Northern fur seal & $10.47^{i}$ & - & - & \\
\hline Ringed seal & $14.86^{j}$ & - & - & \\
\hline Harbour seal pup & $17.05^{k}$ & - & - & \\
\hline $\begin{array}{l}\text { Harbour seal adult } \\
\text { female }\end{array}$ & $12.94^{k}$ & - & - & \\
\hline Gentoo penguin & $10.0^{c}$ & - & - & \\
\hline
\end{tabular}

${ }^{a}$ Arnould, Boyd \& Speakman, 1996; ${ }^{b} \mathrm{MRI}$ unpublished data; ${ }^{\mathrm{C}}$ Forcada et al., 2009; ${ }^{\text {de }}$ Bruyn et al., 2009b; ${ }^{\mathrm{e}}$ Cherel, Charrassin \& Handrich, 1993; ${ }^{\mathrm{f}} \mathrm{Halsey}$ et al., 2008; ${ }^{\mathrm{g}} \mathrm{Crawford}$ et al., 2006; ' Williams et al., 2004; 'Stansby, 1976; 'ंStirling \& McEwan, 1975; ${ }^{\text {K}}$ Bowen et al., 1992. 
Table 4

Number of various prey items required to meet the predicted daily energy requirements of the different agesex classes of killer whales, as well as the total killer whale population, at the Prince Edward Islands.

\begin{tabular}{lrrrrr}
\hline \multicolumn{1}{c}{ Prey type } & $\begin{array}{c}\text { Adult } \\
\text { males }\end{array}$ & $\begin{array}{c}\text { Adult } \\
\text { females }\end{array}$ & Unknown & Calves & $\begin{array}{c}\text { Total } \\
\text { population }\end{array}$ \\
\hline Antarctic fur seal pup & 105 & 244 & 55 & 33 & 438 \\
Antarctic fur seal adult female & 30 & 70 & 16 & 10 & 125 \\
Subantarctic fur seal pup & 93 & 216 & 49 & 29 & 388 \\
Subantarctic fur seal adult female & 25 & 59 & 13 & 8 & 105 \\
Elephant seal pup & 4 & 10 & 2 & 1 & 17 \\
Elephant seal & 1 & 3 & 1 & 0 & 5 \\
King penguin & 61 & 142 & 32 & 19 & 254 \\
Macaroni penguin & 190 & 440 & 100 & 60 & 789 \\
Rockhopper penguin & 324 & 750 & 171 & 102 & 1347 \\
\hline
\end{tabular}


FIGURES

Fig. 1

Proportion of available prey (i.e., percentage of the total prey population) necessary to meet the predicted energetic requirements of the killer whale population at the Prince Edward Islands, over time assuming: (a) killer whales prey exclusively on each prey type, (b) killer whale diet comprised equal proportions (energetically) of each prey type, (c) killer whale diet comprised proportions of prey type relative to their proportional energetic biomass in the Prince Edward Islands system, (d) diet comprised prey proportions relative to their abundance, and (e) diet comprised prey proportions relative to their energy content. AFS Antarctic fur seal adults; AFS P - Antarctic fur seal pups; SFS - Subantarctic fur seal adults; SFS P - Subantarctic fur seal pups; SES - southern elephant seal adults; SES P - southern elephant seal pups; KP - king penguin; MP - macaroni penguin; RP - rockhopper penguin.
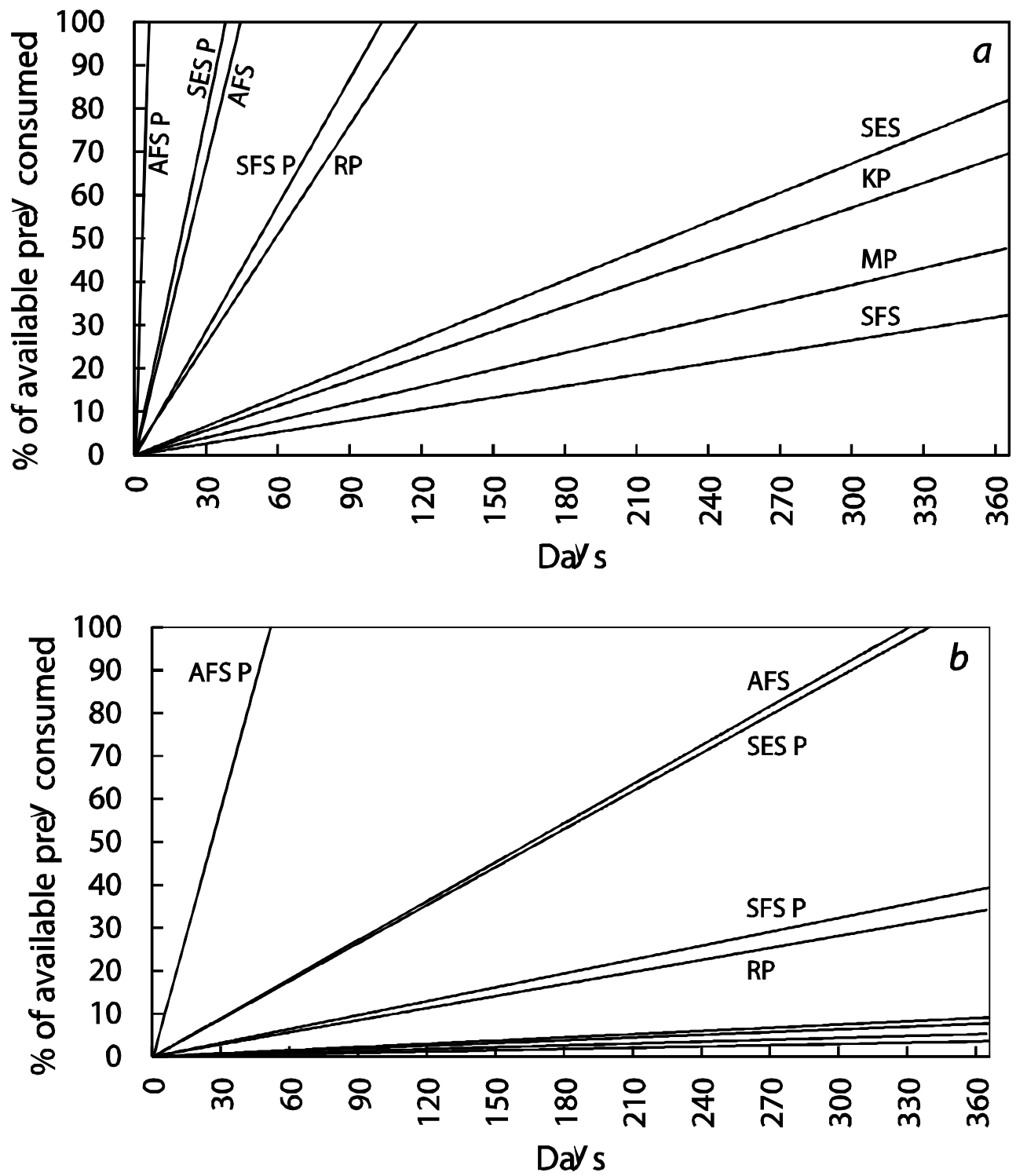

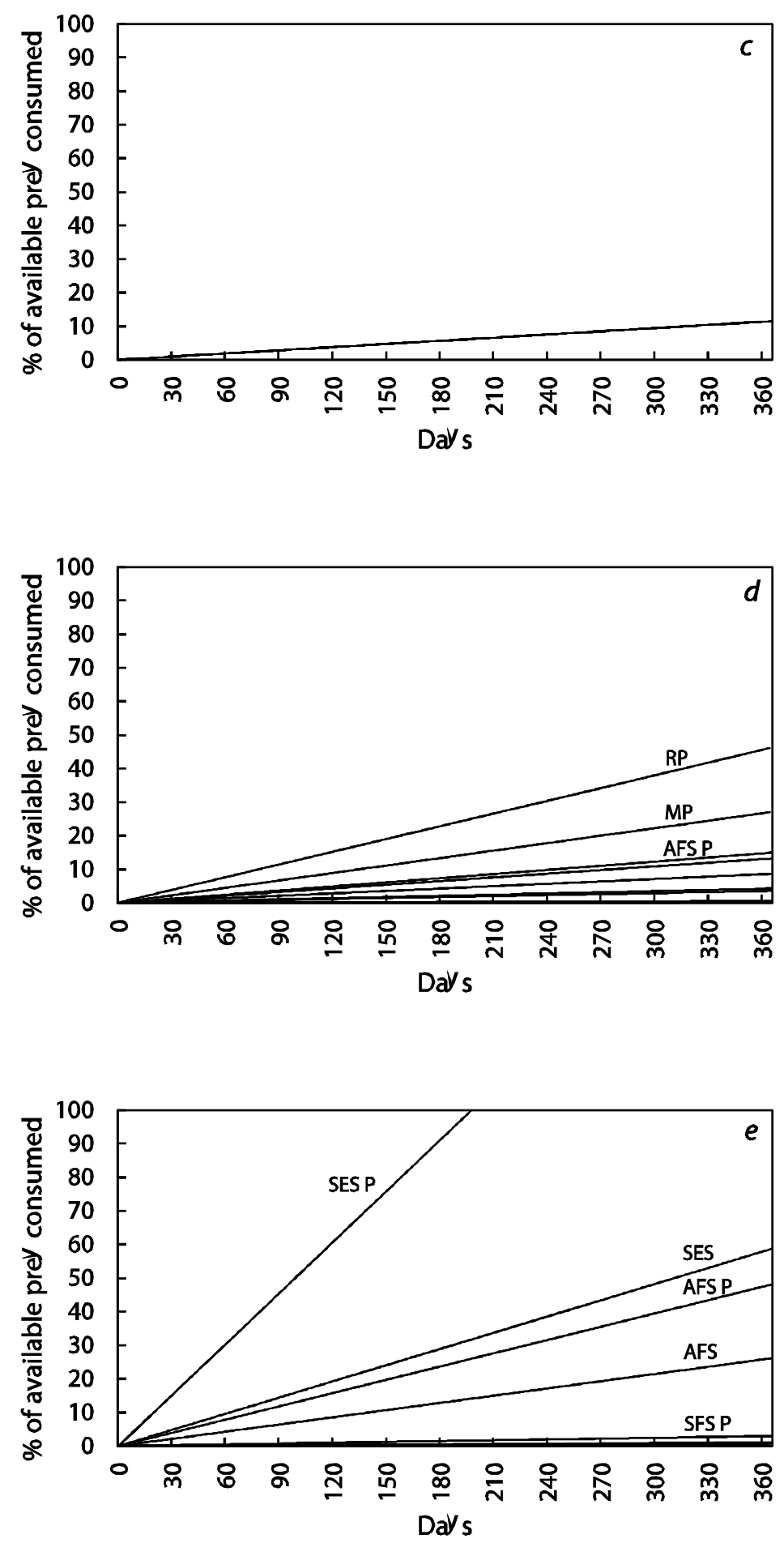

Fig. 2

The effect of killer whale predation on different population sizes of (a) southern elephant seal pups, (b) Antarctic fur seal pups, and (c) Antarctic fur seal adults; assuming three different levels of predation pressure: predation mortality is $10 \%$ of current prey population size (solid lines), 
predation mortality is $20 \%$ of current prey population size (dashed lines), and predation is $40 \%$ of current prey population size (dotted lines).
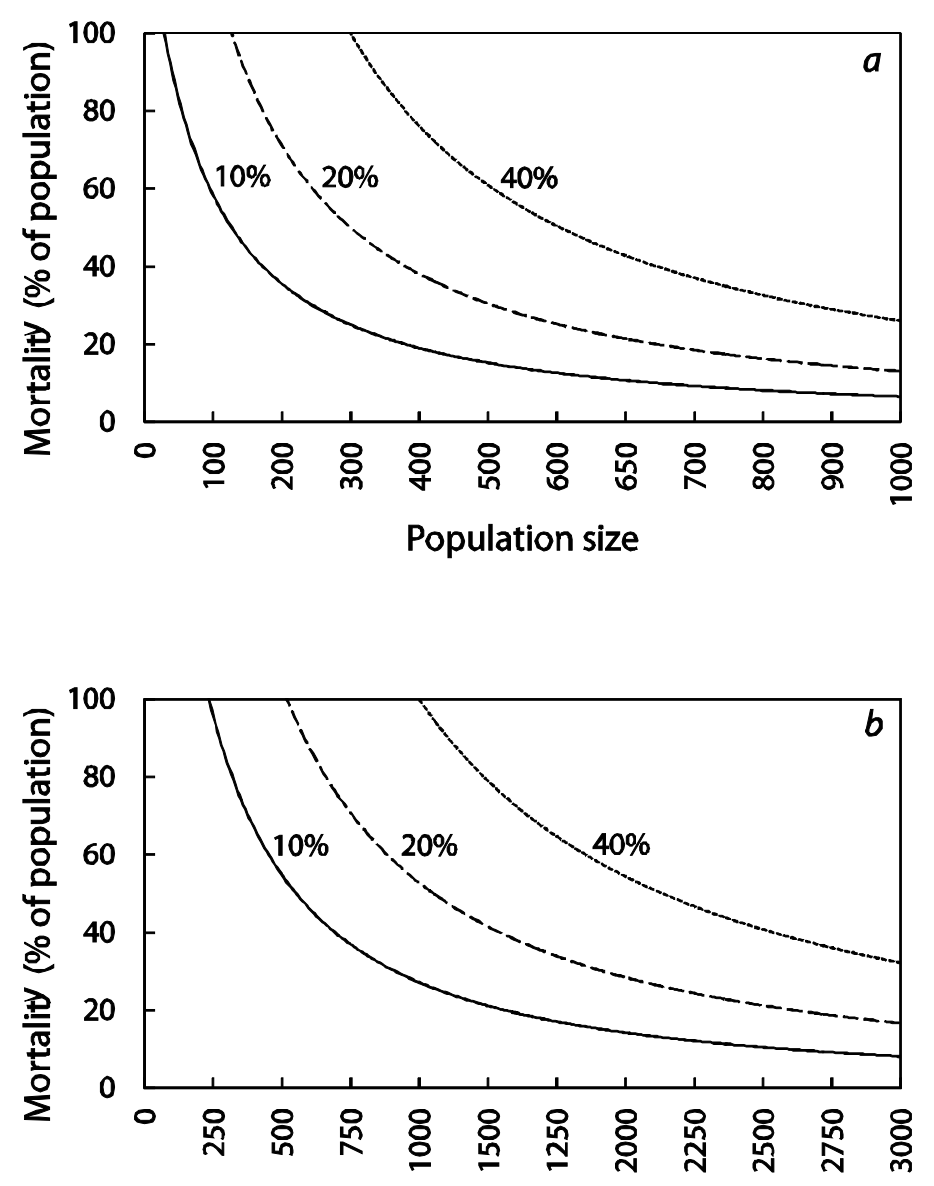

Population size

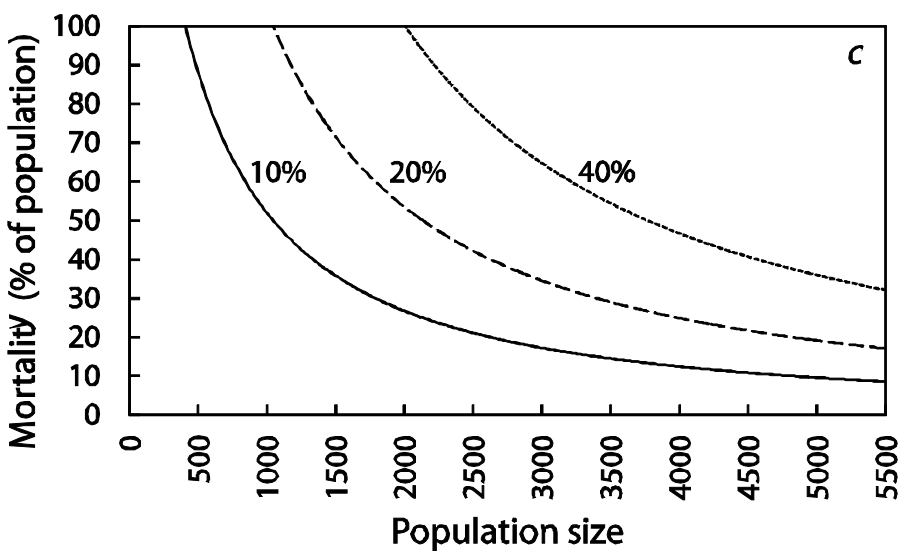


Fig. 3

Potential predatory impact of the Prince Edward Islands killer whale population on southern elephant seal pups prior to their first trip to sea. Solid lines indicate predation assuming killer whales meet all their energy requirements by preying on elephant seal pups $(100 \%)$, and $50 \%$ and $25 \%$ of this predation level. The dashed line indicates the currently observed first year mortality rate for elephant seals at Marion Island.

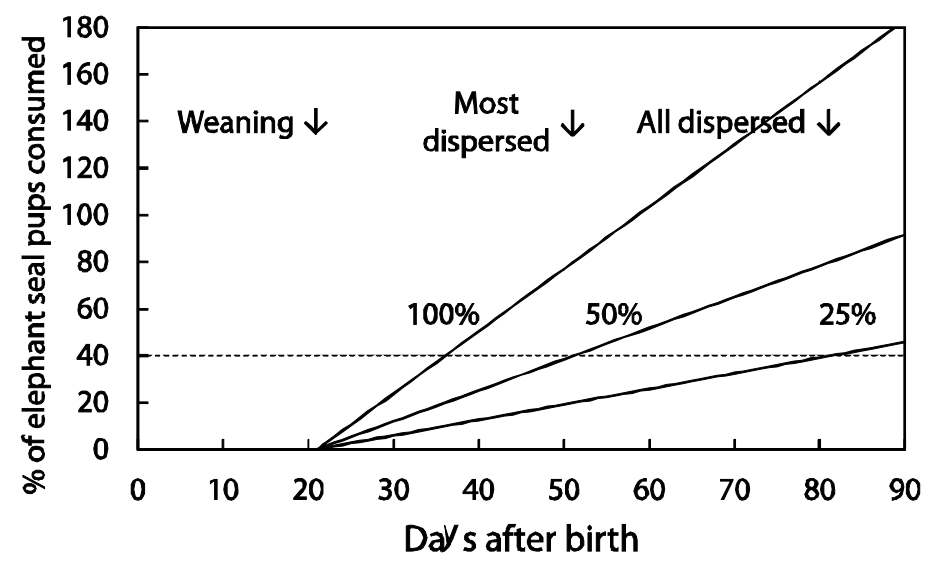

